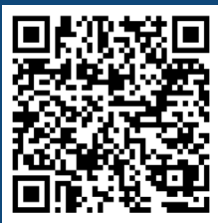

Keywords:

Vegetative propagation

Clonal forestry

Mini-tunne

Historic:

Received $31 / 08 / 2019$

Accepted 05/I I/2019

Correspondence: marcio.navroski@udesc.br
Mariane de Oliveira Pereira ${ }^{\mathrm{la}}$, Marcio Carlos Navroski ${ }^{\mathrm{b}+}$, Alessandro Camargo Ângelo ${ }^{2 a}$, Pedro Henrique Tavares da Fonseca ${ }^{l c}$, Carolina Moraes ${ }^{\prime d}$, Queli Cristina Lovatel ${ }^{\prime e}$, Milena Amaral ${ }^{\prime f}$

\section{ROOTING ENVIRONMENTS IN Sequoia sempervirens MINI-CUTTINGS OF CLONE A228}

PEREIRA, M. O.; NAVROSKI, M. C.; ANGELO, A. C.; FONSECA, P. H.T.; MORAES, C.; LOVATEL, Q. C.; AMARAL, M. Rooting environments in Sequoia sempervirens minicuttings of clone a228. CERNE, v. 25, n. 4, p.386-393, 2019.

\section{HIGHLIGHTS}

Good rooting indexes were obtained (> 80\%), mainly in mini-tunnel.

It is recommended to maintain mini-cuttings for 90 days for proper rooting to occur.

Mini-tunnel was the most efficient place for sequoia mini-cutting.

Favorable environmental conditions are essential for good rooting for the mini-cuttings

\section{ABSTRACT}

Sequoia sempervirens is different from other species not only for its excellent vigor and longevity, but also for quality wood productivity. The objective of this work was to evaluate the rooting of Sequoia sempervirens mini-cuttings in different cultivation environments. In both experiments, rooting was evaluated in time to determine the root development in each environment. Mini-cuttings from clone A228 from clonal mini-garden were used. In the first experiment the material was placed to take root in three different environments: greenhouse $(\mathrm{GH})$, shadehouse $(\mathrm{SH})$ and mini-tunnel, with evaluation performed every 30 days (from 30 to 150 days). In the second experiment, we compared the development and rooting in mini-tunnel, greenhouse with intermittent mist (GWIM), with weekly evaluations (from 30 to 93 days). Both experiments were installed in a completely randomized design, with subsequent evaluation of the survival percentage, percentage of rooted cuttings and number of roots emitted by rooted cuttings. Humidity and temperature data were also collected in all environments observed. The mini-tunnel was the most efficient place for sequoia minicutting, presenting higher survival, rooting and number of roots when compared to the shadehouse and the greenhouse. In addition, it provided rooting similar to the greenhouse with intermittent mist (close to $90 \%$ ). It is recommended to keep mini-cuttings in a minitunnel or greenhouse with intermittent mist for a period of 90 days for proper rooting to occur. Good temperature control was also observed in this structure, as well as excellent humidity control. The mini-tunnel can be used for sequoia propagation by mini-cuttings as it has shown good rooting results ( $>80 \%)$.
State University of Santa Catarina, Lages, Santa Catarina, Brazil- ORCID: 0000-000 I-55I8-7464a, 0000-0002

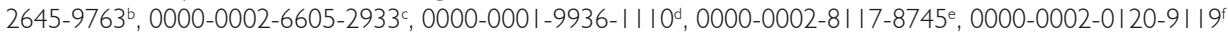

2 Federal University of Paraná, Curitiba, Paraná, Brazil - ORCID: 0000-0003-4279-2635 


\section{INTRODUCTION}

Intensified production of planted forests, together with sustainable management of natural forests, plays a relevant role in protecting and conserving natural ecosystems. In this sense, tests with new species are necessary to have reliable production protocols. Amid the potential species is Sequoia sempervirens (D. Don) Endl., popularly known as sequoia.

Sequoia is the tallest tree species in the world (Luna, 2008), with its trees reaching heights greater than $110 \mathrm{~m}$. It is a species capable of storing large amounts of biomass, more than any other ecosystem (Van Pelt et al., 2016). The average annual increment and the annual periodic increment correspond to values of 33.2 and 75.6 $\mathrm{m}^{3} \mathrm{ha}^{-1}$ year-1, respectively, in young sequoia plantation. Similarly, the periodic carbon increment may exceed 16 tons ha $^{-1}$ year-1 (Jones and O'Hara, 20I2).

It is a remarkable species due to its rapid growth, large sizes achieved by individual trees, longevity and durability of its wood. In addition, it is the only conifer with high budding potential (O'Hara and Berrill, 2009). Its wood is one of the most productive in the United States and provides an important high-quality supply in the country. However, although sequoia has an exceptional ability to withstand and grow after disturbances such as fires, floods, landslides, very little is known about the characteristics that influence clonal dissemination (Douhovnikoff et al., 2004).

Vegetative propagation is an alternative that can be used to work with sequoias, and the techniques vary among propagators (Luna, 2008). Cuttings and minicuttings are commonly used as vegetative multiplication methods most commonly used for cloning woody plants (Dias et al., 20I2). The success of this technique depends on several factors that are directly related to rooting, varying for each species, according to the subsequent treatment, being the easiness of rooting explained by the knowledge of intrinsic factors such as physiological stage, hormonal balance, juvenility and age of the parent plant, and extrinsic to the material, such as season, light, temperature and humidity (Rios et al., 20I2; Wendling et al., 20I4).

The environment for rooting in the initial phase should allow the survival of vegetative propagules, mainly by controlling the relative humidity and temperature (Hartmann et al., 20I I). The infrastructure of a nursery varies according to the need for production scale, nursery size, technological level and resource availability. Advances in technology have enabled the development of plant propagation facilities such as mist chambers, roofs and greenhouses with automated systems. Mist systems keep air humidity high, allowing plants to multiply by leaf cuttings (Fachinello et al., 2005).

These intermittent irrigation systems are costly installations, making it impossible for small producers to use technology In addition, improper mist management can lead to excess moisture on rainy or cloudy days, which hinders gas exchange, prevents rooting, causes tissue death and facilitates the emergence of fungal diseases in the cuttings (Zanardi and Garlet, 20I4).

For cloning of some species, as an example of Eucalyptus genus, the mini-cutting technique is already applied on a commercial scale, however, it requires special installations with automation systems, which increases the production costs. As an alternative to rooting vegetative propagules it is possible to test other simpler environmental control systems, which can also provide satisfactory rooting as well as being cheaper.

From the implementation of mini-cutting technique, several alternatives have emerged to improve the structures available for plant propagation, growth and development. One option that has been used in clonal propagation is the mini-tunnel, a protected environment that covers a smaller, tunnelshaped, plastic-lined area. Results show that the use of this type of structure keeps the environment moist and warm, increasing rooting (Pereira et al., 20/8).

The objective of this work was to evaluate the rooting of Sequoia sempervirens mini-cuttings of clone A228 in different cultivation environments and to determine the rooting and maintenance period of the mini-cuttings in the cultivation environment.

\section{MATERIAL AND METHODS}

\section{Origin of reproductive material}

Propagule sources used in the experiment were select from sequoia matrices (located in São Francisco de Paula, Rio Grande do Sul state, Brazil) with approximately 40 years of age, propagated by the conventional cutting technique. After 120 days, propagules were collected from the parent plant obtained by total girdling or partial girdling. The material was transported in styrofoam boxes with ice (transport lasted approximately 4 hours) to the Forest Nursery located in Lages, Santa Catarina state, Brazil. After that, cuttings with a size of $10 \mathrm{~cm}$ containing a pair of acicular leaves were reduced to $50 \%$ of the leaf area and were treated with $6,000 \mathrm{mg} \cdot \mathrm{L}^{-1}$ of indole-3-butyric acid (IBA). Then, the cuttings were placed in tubes $\left(180 \mathrm{~cm}^{-3}\right)$ containing vermiculite and 
commercial substrate (peat, vermiculite, pine bark and charcoal) and kept in a mini-tunnel for rooting.

After cutting, five-month-old rooted seedlings were acclimatized in shadehouse. Subsequently, seedlings approximately $20 \mathrm{~cm}$ tall were transferred to $5 \mathrm{~L}$ vases filled with peat and pine bark-based commercial substrate (50\%) and medium-sized vermiculite (50\%). Monthly, during four months, pruning of the mini-ceps was performed. The nutrient solution used in the clonal mini-garden was the basis of commercial fertilizer (composed of $10 \% \mathrm{~N} ; 42 \%$ $\mathrm{P}_{2} \mathrm{O}_{5}$ (water soluble); $10 \% \mathrm{~K}_{2} \mathrm{O}$ (water soluble); $0.6 \% \mathrm{Mg}$; $0.1 \% \mathrm{Fe}$ and $0.02 \mathrm{Br}$ ), with fertigation carried out twice a week. After the period of mini-cep formation, shoots were collected for the experiments.

Rooting of mini-cuttings in mini-tunnels, shadehouse and greenhouse

Shoots obtained by the clonal mini-garden system (only the clone A228) were collected for the preparation of mini-cuttings $8-10 \mathrm{~cm}$ long. The basal portion was bevel cut and the upper portion incised transversely, keeping a pair of half-cut acicular leaves. The mini-cuttings were placed in $180 \mathrm{~cm}^{3}$ polypropylene tubes, containing the blend of commercial substrate and vermiculite $(\mathrm{I}: \mathrm{I} / \mathrm{v} / \mathrm{v})$, with the base of the mini-cutting inserted approximately $2 \mathrm{~cm}$ in the substrate, without using plant growth regulators. According to the manufacturer's information, the substrate is composed of peat, expanded vermiculite, pine bark, and charcoal. To the substrate was also added $6 \mathrm{~d} \mathrm{~L}^{-1}$ of controlled fertilization.

The trays containing the mini-cutting tubes were placed in three rooting environments (treatments). Initial rooting environments differed mainly in temperature and humidity management, using a greenhouse $(\mathrm{GH})$ with a low-density, transparent, I50-micron polyethylene cover, a mini-tunnel and a shadehouse $(\mathrm{SH})$ with a shade cover (30-35\%) nylon type. The mini-tunnel is a single structure with the same roof as the greenhouse (polyethylene low-density, transparent, 150-micron) located inside the shadehouse and with the following dimensions: $8.0 \times 1.20 \times 0.9 \mathrm{~m}$ (length $\times$ width $\times$ height). None of the environments has any kind of temperature and humidity control, being unique to the materials used to cover and insulate the environments.

All sites received the same intensity and frequency of irrigation, with four daily irrigations (9:00 AM; 12:00 AM; 3:00 PM; 6:00 PM) of 10 minutes each, using the micro-sprinkler system. Daily, at 1:00 PM, temperature $\left({ }^{\circ} \mathrm{C}\right)$ and relative humidity ( $\left.\mathrm{RH} \%\right)$ were measured using Politerm datalogger, model Pol-49. The average weekly values of temperature and humidity in the three rooting environments can be observed in Figure I.

The experiment was carried out from February to July 2016, and was conducted in a completely randomized design, in a $3 \times 4$ factorial scheme (three rooting environments and four evaluation periods), using 5 replications of 5 cuttings per experimental unit. Evaluations were performed every 30 days, starting from the day 30 day after the cutting until the day 150.

Rooting of mini-cuttings in greenhouse and greenhouse with intermittent mist

Due to the results obtained in the previous experiment, a new study was carried out to evaluate the rooting of cuttings in the mini-tunnel and in a greenhouse with intermittent mist (GWIM). In this experiment, as well as in the first one, we used mini-cuttings of A228 clone collected from the clonal mini-garden, and the collection procedures, pattern of mini-cuttings, substrate and containers used were the same as described above.

After cutting, the trays containing the tubes were placed in two different rooting environments: mini-tunnel and GWIM. In this latter environment, the greenhouse is automated, with temperature control $\left(\mathrm{T} \leq 30^{\circ} \mathrm{C}\right)$ and air relative humidity $(\mathrm{RH}>80 \%)$.

The water management in the greenhouse consisted of five daily irrigations (9:00 AM; II:30 AM; I:30 PM; 3:30 PM, 6:00 PM) of 7 minutes each, using the micro-sprinkler system. At GWIM, irrigation was performed by mist as indicated on the basis of air relative humidity and temperature. At both sites, humidity and temperature data were collected by datalogger, with readings taken every 10 minutes. The average weekly values of temperature and humidity in the two rooting environments can be observed in Figure 2.

The experiment was carried out from May to July 2017, and was conducted in a completely randomized design, in a $2 \times 10$ factorial scheme (two rooting environments and ten evaluation periods), using 5 replications of 5 cuttings per experimental unit. Evaluations were performed every week ( 10 weeks), starting from the day 30 day after the cutting until the day 93 , a time when the cutting was stabilized.

\section{Evaluations and statistical analysis}

In both experiments, the survival percentage was evaluated; percentage of rooted mini-cuttings and number of roots emitted by rooted mini-cuttings. Mini-cuttings with live wood, old leaves or young shoots, rooted or not, were considered survivors. The 

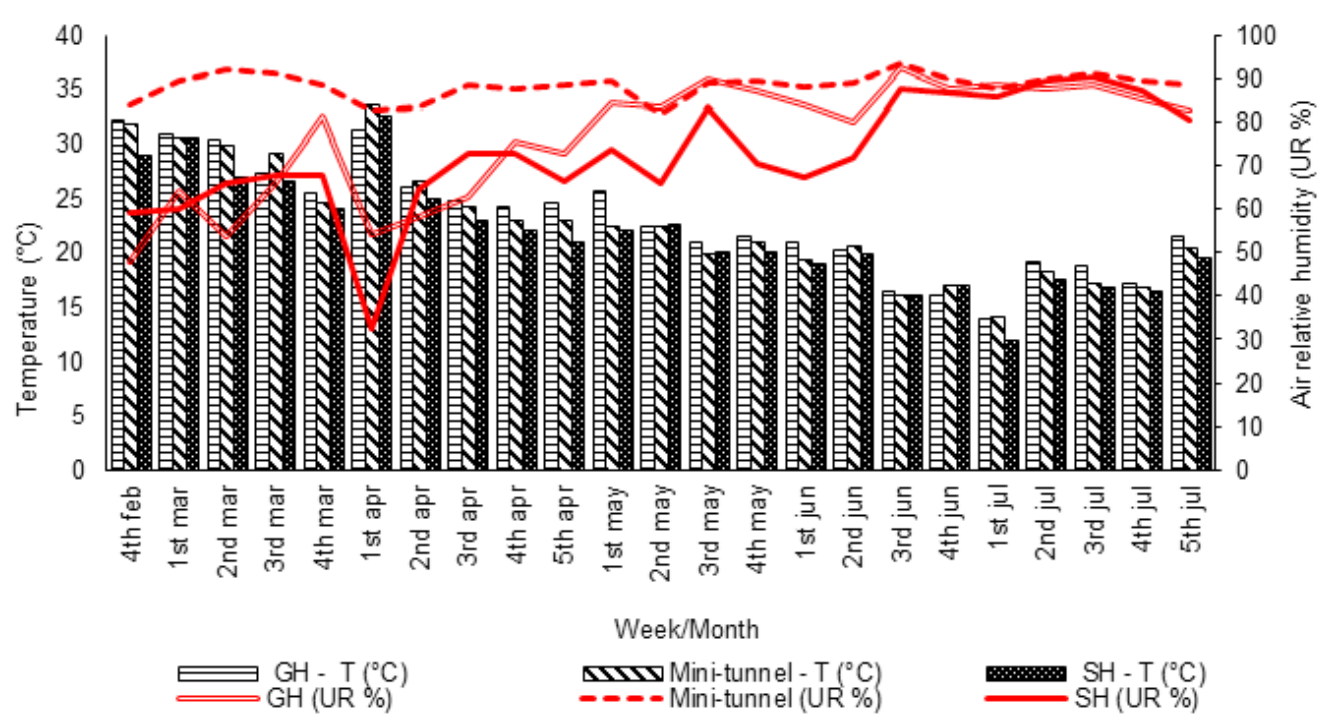

FIGURE I Weekly averages (4th week of February to 5 th week of July) of temperature $\left({ }^{\circ} \mathrm{C}\right)$ and air relative humidity (\%) in the three rooting environments (greenhouse- $\mathrm{GH}$, mini-tunnel and shadehouse - $\mathrm{SH}$ ) of Sequoia sempervirens mini-cuttings

percentage of rooted mini-cuttings was analyzed over the total, not only in function of the surviving minicuttings. Rooted mini-cuttings were those with root primordia greater than $2 \mathrm{~mm}$. Root number evaluation was performed only at the last evaluation, 150 days after cutting. In both studies the mini-cuttings evaluated in one period were no longer used in the next evaluations to avoid interference with their removal and replacement.

After checking the normality of the data through the Kolmogorov-Smirnov test and the homogeneity by the Bartlet test, the variance analysis was performed. When necessary, the data were transformed by the function $(x+0.5)^{0.5}$ and the averages were compared by Tukey test or $5 \%$ probability polynomial regression.

\section{RESULTS AND DISCUSSION}

Rooting of mini-cuttings in mini-tunnels, shadehouse and greenhouse

In relation to propagation environments, the material placed in mini-tunnel achieved superior results regarding the percentage of surviving mini-cuttings (Figure 3a) during the initial storage period for the production of sequoia seedlings by mini-cutting. There was a relatively small mortality rate in mini-tunnel-packed mini-cuttings (I8\%), high in the shadehouse (58\%) and a significant gradual increase in the greenhouse (83\%) (Figure 3).

It is important to highlight the high cuttings mortality after the day 60 in the shadehouse environment.

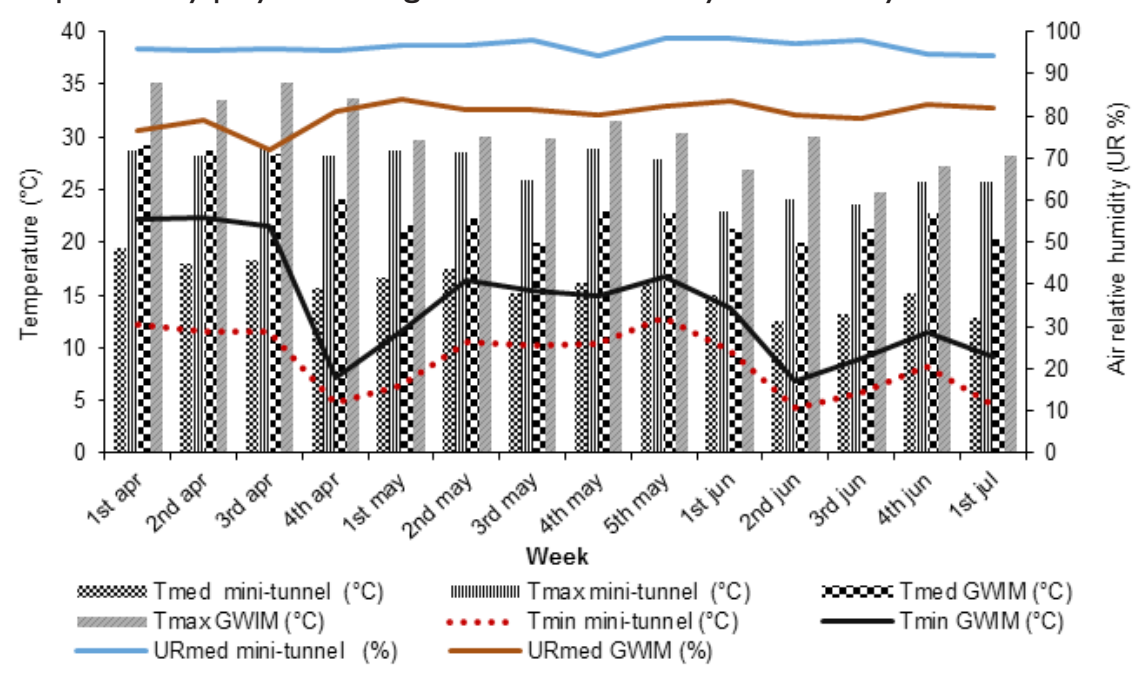

FIGURE 2 Weekly averages (I st week of April to Ist week of July) of average temperature - Tmed $\left({ }^{\circ} \mathrm{C}\right)$, maximum temperature - Tmax $\left({ }^{\circ} \mathrm{C}\right)$, minimum temperature - Tmin $\left({ }^{\circ} \mathrm{C}\right)$ and air relative humidity - URmed $(\%)$ in the two rooting environments (mini-tunnel and greenhouse with intermittent mist - GWIM) of Sequoia sempervirens mini-cuttings.. 


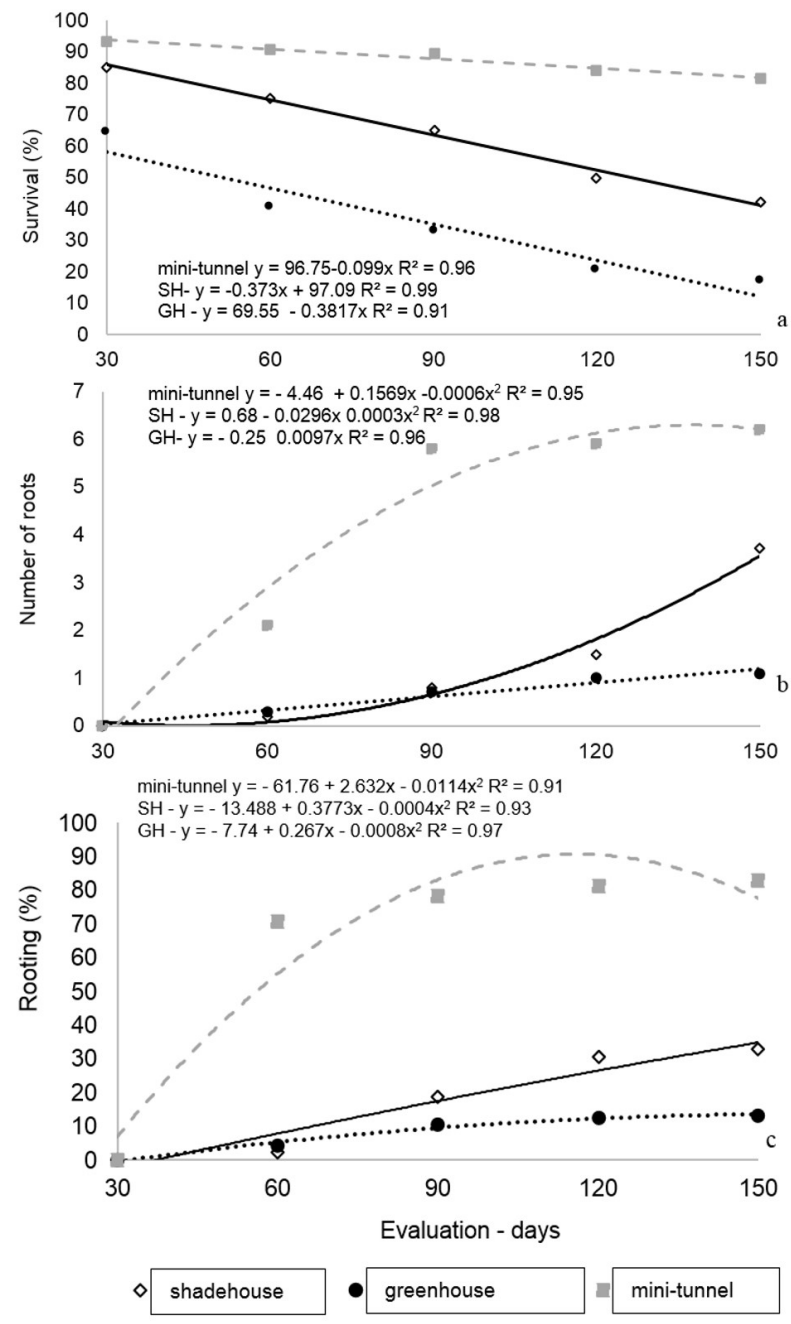

FIGURE 3 (a) Survival - \%; (b) number of roots and (c) rooting -\%; of Sequoia sempervirens mini-cuttings in different rooting environments, evaluated monthly from 30 to I 50 days. (Significant interaction: $p=0.012$ - survival; $p<0.00$ I rooting and $p=0.002$ - number of roots).

This increase was possibly due to the lack of mini-cutting rooting, with subsequent exhaustion of them, due to the end of the internal reserves used to maintain the material after the cutting preparation (Costa et al., 20I3). In the greenhouse environment, due to environmental factors such as high temperature and low humidity (Figure I), there was high mortality (60\%) in the first 60 days of cultivation.

These results are mainly related to a better control of temperature and air relative humidity in the mini-tunnel, since in this environment the relative humidity remained close to $90 \%$ throughout the experimental phase. In the shady and greenhouse there was a large variation in humidity, sometimes very low, a factor that is limiting the cuttings survival. In this regard, Dias et al. (2015) recommend maintaining air humidity above $80 \%$, thus preserving propagule turgidity, as they have no means to absorb water and nutrients. The use of greenhouses and mini-tunnels in agriculture, horticulture and forestry has considerably changed the environments available for plant growth and propagation, providing partial control of climate effects (Batista et al., 20I5).

For rooting, more contrasting responses were observed between the different environments. In the first evaluation (30 days) there was no rooting in any environment. However, 60 days after cutting, a high percentage $(>70 \%)$ was observed in mini-tunnel-filled mini-cuttings, while in shadehouse and greenhouse the rooting was less than $5 \%$ (Figure $3 c$ ).

The rapid rooting obtained in the mini-tunnel was made possible thanks to the climatic conditions found in this place. According to data collected from the period (Figure I), the temperature was close to $25^{\circ} \mathrm{C}$ and the relative humidity was over $80 \%$. In the other environments the average temperature was similar to the mini-tunnel, however the humidity presented levels below $50 \%$, especially in the shadehouse, which has less climate control. The need for water for the cuttings to take root is based on the fact that soon after placing them on the substrate they have no roots, and therefore cannot absorb enough water to compensate for perspiration and the growth of new shoots (Fernandes et al., 20I8). According to Fachinello et al. (2005), rooting occurs only in tissues with turgid cells, and it is essential to maintain an adequate water content in the substrate and aerial part of the cuttings.

Mini-cuttings kept in mini-tunnel, 60 days after cutting, had an increase of approximately $10 \%$, reaching $83 \%$ in the evaluation made at day 150. Nevertheless, it is not recommended to keep mini-cuttings for more than 90 days in a rooting environment, due to the occurrence of higher mortality (Figure 3a), high chance of disease appearance, increased activities such as maintenance and cleaning, and especially due to the long time spent in the nursery facilities, which increases labor costs.

For mini-cuttings kept in a shadehouse, a residence time of $\mathrm{I} 20$ days is recommended, and a rooting rate of around $30 \%$ can be observed. This rooting result can be considered low considering other works with the species, usually with cuttings or mini-cuttings kept in a greenhouse. Pereira et al. (2018) found rooting over $85 \%$ in all seasons of the year. Navroski et al. (2015) achieved rooting of almost $80 \%$ using $4,000 \mathrm{mg} \mathrm{L}^{-1}$ of AIA (indole-3-acetic acid). Rooting results greater than $60 \%$ were also obtained for Sequoia sempervirens by Pereira et al. (2017a) and Pereira et al. (20I7b). 
The increase in rooting time in this type of site is related to less climate control, especially in relation to thermal variation, with low temperatures at night and lower values during the day, when compared to the mini-tunnel and the greenhouse. Abrupt temperature variations are detrimental to cutting rooting, altering nutrient uptake and metabolism (Cunha et al., 2009).

Greenhouse cuttings had lower rooting rates, with values just over $10 \%$. As with a mini-tunnel, it is not recommended to keep mini-cuttings in this environment for more than 90 days, as there is no substantial increase in rooting. Therefore, this type of environment is not recommended for rooting of sequoia mini-cuttings due to the high mortality rate, resulting in a low number of rooted mini-cuttings. Although sequoia mini-cuttings have lower sensitivity compared to other species, especially those of the genus Eucalyptus, adequate temperature conditions (close to $25^{\circ} \mathrm{C}$ ) and mainly humidity (over $80 \%$ ) are important to obtain good rooting rates in less time. According to Ragonezi et al. (2010) the majority of works with conifer rooting achieve better results with higher temperatures during the day $\left(25-27^{\circ} \mathrm{C}\right)$ and lower during the night $\left(15-18^{\circ} \mathrm{C}\right)$. Testing the rooting of Sequoia sempervirens in all seasons of the year, Pereira et al. (2018) found rooting higher than $85 \%$ in all seasons, with average temperatures ranging from 15 to $26^{\circ} \mathrm{C}$.

For root formation the results were similar to those of rooting, with greater root formation in the mini-cuttings kept in mini-tunnel (Figure 3b), tending to stabilization after 90 days of evaluation, thus reinforcing the absence of material maintenance required in the rooting environment for periods longer than 90 days. In the greenhouse environment there was formation of low number of roots, even keeping the mini-cuttings for longer periods. In the shadehouse it was possible to observe a larger number of roots only at 150 days, showing the need for a longer period for the minicuttings to root in this environment.

The good results obtained in this work using the mini-tunnel are corroborated by Assis (20I I), who emphasizes that the use of mini-tunnels accelerates and raises the rooting of Eucalyptus species mini-cuttings. Therefore, Batista et al. (2015) mention the use of minitunnels to improve the quality of propagule rooting system in clones of some species of the same genus. Good results on cutting rooting with the use of minitunnels were also found for the mini-ixora species (Ixora coccinea), and the mini-tunnel is called humid chamber (Almeida et al., 2008). According to the authors, the humid chamber was the environment that provided the best conditions for propagation of the species, with higher rooting percentage (98\%) compared to intermittent mist $(66 \%)$ and traditional rooting - greenhouse (10\%).

Rooting of mini-cuttings in mini-tunnel and greenhouse with intermittent mist

Regarding cuttings survival, no difference was observed between the two environments $(p=0.924)$ and between the evaluations $(p=0.530)$. The average survival was $97.8 \%$ after 93 days of cutting. These results demonstrate the high environmental control in both structures.

Regarding rooting, it was not possible to observe it in the mini-cuttings in any of the environments in the evaluation performed at 30 days (Figure 4a). At 37 days there was a significant rooting $(41 \%)$ in the greenhouse environment with intermittent mist, but null in the minitunnel. In this place, the beginning of the root formation was observed at 44 days and this difference in the initial rooting, mainly until the $5 \mathrm{I}^{\text {st }}$ day, attributed to the lower average temperature in the mini-tunnel (Figure 2) and mainly to the minimum temperatures registered, with values lower than $5^{\circ} \mathrm{C}$ in the fourth week after cutting. The period from 30 to 40 days is the phase in which high tissue differentiation occurs, with root formation from callus or by direct route. Thus, low temperatures tend to delay the onset of rooting (Hartmann et al., 20l I), as observed in mini-cuttings kept in a mini-tunnel environment.
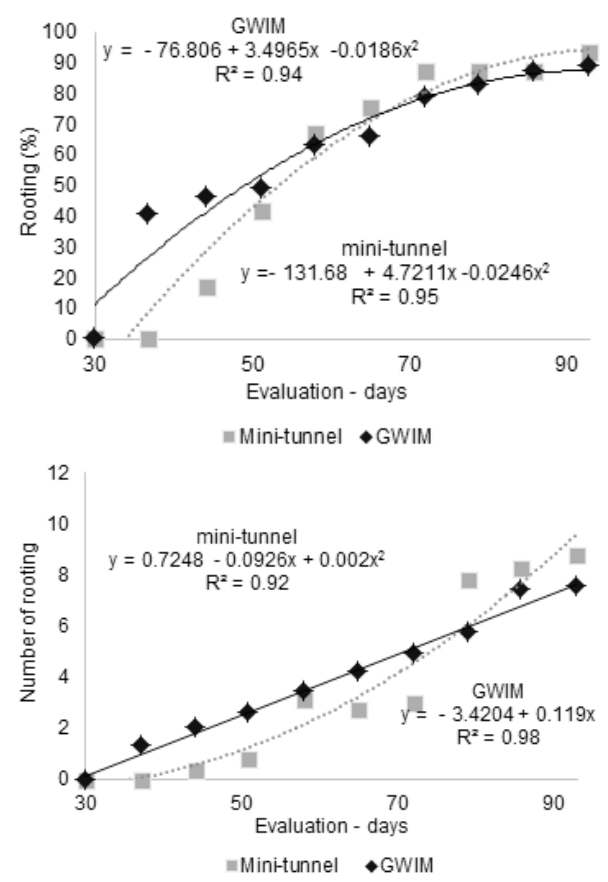

FIGURE 4 Rooting -\% (a) and number of roots (b) in Sequoia sempervirens mini-cuttings in intermittent mist greenhouse (GWIM) and mini-tunnel environments, with weekly evaluation between 30 and 93 days. (Significant interaction. Rooting: $p=0.013$ and number of roots: $p=0.0237)$.. 
From 5 I days until the end of the evaluation (93 days) it was not possible to observe great variation in the rooting between the two environments. There is a greater progression of root formation in the mini-tunnel environment, reaching $87 \%$ in the evaluation performed at 72 days. The maximum rooting in this environment was obtained in the last evaluation, reaching almost $95 \%$. In greenhouse with intermittent mist the maximum rooting did not exceed $90 \%$. In both structures it is recommended to maintain mini-cuttings until the $90^{\text {th }}$ day, thus seeking to achieve good rooting rates.

Root formation increased over time, tending to stabilize from the evaluation made at day 86 (Figure 4b). In the greenhouse, it was possible to observe a larger root formation from 79 days, resulting in approximately 8 roots per cut. In vegetative propagation, besides the rooting percentage, the number of roots formed is important to reflect the quality of the seedling, since a better root system will result in a better chance of survival when the seedlings are transplanted to the field (Raasch et al., 20I3). Luna (2008) highlights that even suitable for rooting, sequoia cuttings can have high mortality in acclimatization process, and care should be taken with environmental conditions, especially in relation to high temperatures.

It is important to highlight the good rooting and root formation index in a mini-tunnel environment, low cost place for installation, easy maintenance, good temperature control and especially humidity. This type of structure can cheapen the process of seedling production by cuttings and mini-cuttings, and should also be tested for other species.

In a similar experiment, performed by Brondani et al. (2007), evaluating the effect of rooting environment on mate cuttings (llex paraguariensis), the authors verified that in the automated greenhouse (intermittent mist) the best rooting percentages were observed. However, they found that the simple greenhouse can also be used for rooting species, as long as the mini-cuttings stay longer in this environment to form a more vigorous root system.

Depending on the environmental conditions of the place where the mini-cuttings of different species are to be rooted, which propagation environment will provide the most appropriate conditions for the success of the activity should be noted, considering a cost compatible with the need.

\section{CONCLUSIONS}

The mini-tunnel is the most efficient place for sequoia mini-cutting, presenting higher survival, rooting and number of roots compared to the shadehouse and the conventional greenhouse. This location provides a rooting similar to the greenhouse with intermittent mist, and is suitable for storage of mini piles.

It is recommended to keep mini-cuttings in a mini-tunnel or greenhouse with intermittent mist for a period of 90 days for proper rooting to occur (close to $90 \%$ ) and greater root formation.

\section{ACKNOWLEDGMENTS}

The authors thank FAPESC for funding the research group Management of Planted and Natural Forests (PAP2019031000055).

\section{REFERENCES}

ALMEIDA, F. D.; XAVIER, A.; DIAS, J. M. M.; PAIVA, H. N. Eficiência das auxinas (AIB e ANA) no enraizamento de miniestacas de clones de Eucalyptus cloeziana F. Muell. Revista Árvore, v. 3I, n. 3, p. 455-463, 2007.

ASSIS T, F. Hybrids and mini-cutting: a powerful combination that has revolutionized the Eucalyptus clonal forestry. In: IUFRO Tree Biotechnology Conference 201 I: From Genomes to Integration and Delivery. BMC Proceedings, n. 5 (Suppl 7): II8. 2011.

BATISTA A. F., SANTOS, G. A.; SILVA, L. D.; QUEVEDO, F. F. AThe use of mini-tunnels and the effects of seasonality in the clonal propagation of Eucalyptus in a subtropical environment. Australian Forestry, v. 78, p. 65-72. 2015.

COSTA, C. T.; ALMEIDA, M. R.; RUEDELL, C. M.; SCHWAMBACH, J.; MARASCHIN, F. S.; FETT-NETO, A. $G$. When stress and development go hand in hand: main hormonal controls of adventitious rooting in cuttings. Frontiers in Plant Science, v. 4: p. 1-19, 2013.

CUNHA, A. C. M. C. M.; PAIVA, H. N.; LEITE, H. G.; BARROS, N. F.; LEITE, F. P. Influência do estado nutricional de minicepas no enraizamento de miniestacas de eucalipto. Revista Árvore, v.33, n.4, p.607-615, 2009.

DIAS, P. C.; ATAÍDE, G. M.; XAVIER, A.; OLIVEIRA, L. S.; PAIVA, H. N. Vegetative propagation of Schizolobium amazonicum by cutting. Cerne, v. 2 I n. 3, p. 379-386, 2015.

DIAS, P. C.; OLIVEIRA, L. S.; XAVIER, A.; WENDLING, I. Estaquia e miniestaquia de espécies florestais lenhosas do Brasil. Pesquisa florestal brasileira, v. 32, n. 72, p. 453-462, 2012.

DOUHOVNIKOFF, V.; CHENG, A. M.; DODD, R. S. Incidence, size and spatial structure of clones in second-growth stands of coast redwood, Sequoia sempervirens (Cupressaceae). American Journal of Botany, v. 91, n.7, p. I |40-I | 46, 2004.

FACHINELLO, J. C.; HOFFMANN, A.; NACHTIGAL, J. C. Propagação vegetativa por estaquia. In: FACHINELLO, J. C. HOFFMANN, A.; NACHTIGAL, J. C. Propagação de plantas frutíferas. Pelotas: Embrapa Informações Tecnológicas, p. 69-109, 2005. 
FERNANDES, S. J. O.; SANTANA, R. C.; SILVA, E. B.; SOUZA, C. M. P.; SILVA, C. T. Período de enraizamento de miniestacas de eucalipto provenientes de diferentes lâminas de irrigação em minijardim. Ciência Florestal, v. 28, n. 2, p. 59I-600, 2018.

HARTMANN, H. T.; KESTER, D. E.; DAVIES JR., F. T.; GENEVE, R. L. Plant Propagation: principles and practices. 8. ed. New Jersey: Prentice Hall, 9I 5 p, 201 I.

JONES, D. A.; O'HARA, K. L. Carbon density in managed coast redwood stands: Implications for forest carbon estimation. Forestry, v. 85, n. I, p. 99-110, 2012.

LUNA, T. Vegetative Propagation of Coastal Redwood (Sequoia sempervirens (Lamb. ex D. Don) Endl.). Native Plants Journal, v. 9, n. I, p. 25-28. 2008.

NAVROSKI, M. C.; PEREIRA, M. O.; HESS, A. F.; SILVESTRE, R.; ÂNGELO, A. C.; FAZZINI, A. J.; ALVARENGA, A. A. Resgate e propagação vegetativa de Sequoia sempervirens. Floresta, v. 45, n. 2, p. $383-392,2015$.

O'HARA, K. L.; BERRILL, J. P. Epicormic sprout development in pruned coast redwood: pruning severity, genotype, and sprouting characteristics. Annals of Forest Science, v. 66, p. $409-417,2009$.

PEREIRA, M. O.; ÂNGELO, A. C.; NAVROSKI, M. C.; DOBNER JÚNIOR M.; OLIVEIRA, L. M. Vegetative rescue and rooting of cuttings of different stock plants of Sequoia sempervirens. Cerne, v. 23, n. 4, p. 435-444, 20I7a.

PEREIRA, M. O.; NAVROSKI, M. C.; ÂNGELO, A. C.; FRIGOTTO, T.; MENEGUZZI, A.; FELIPPE, D. Enraizamento de estacas de Sequoia sempervirens (D. Don) Endl. em função de concentrações e reaplicações de AIB. Espacios, v. 38, n. 21, p. 15-26, 2017b.
PEREIRA, M. O.; ÂNGELO, A. C.; NAVROSKI, M. C.; NICOLETTI, M. F.; NASCIMENTO, B.; SÁ, A. C. S.; GASPARIN, E.; LOVATEL, Q. C. Roots of mini-cutting of clones of Sequoia sempervirens in different seasons of the year. Cerne, v. 24, n. 4, p. 452-460, 2018.

RAASCH, L. D.; BONALDO, S. M.; OLIVEIRA, A. A. F. Bacillus subtilis: enraizamento e crescimento de miniestacas de eucalipto em Sinop, norte de Mato Grosso. Bioscience Journal, v. 29, n.5, p. I446-I457, 2013.

RAGONEZI, K.; KLIMASZEWSKA, K.; CASTRO, M. R.; LIMA, M.; OLIVEIRA, P.; ZAVATTIERI, M. A. Adventitious rooting of conifers: influence of physical and chemical factors. Trees, v.24, n. I, p.975-992, 2010.

RIOS, S. E. M. C., PEREIRA, L. S., SANTOS, T. C., SOUZA, V. G. R. Concentrações de acido indol butírico comprimento e época de coleta de estacas na propagação de umbuzeiro. Revista Caatinga, v. 25, n. I, p. 52-57, 2012.

VAN PELT, R.; SILLETT, S.; KRUSE, W. A.; FREUND, J. A.; KRAMER, R. Emergent crowns and light-use complementarity lead to global maximum biomass and leaf area in Sequoia sempervirens forests. Forest Ecology Management, v. 375, n. I, p. 279-308, 2016.

WENDLING, I.; TRUEMAN, S, XAVIER, A. Maturation and related aspects in clonal forestry-part II: reinvigoration, rejuvenation and juvenility maintenance. New Forests, v.45, n.4, p. I-I4, 2014.

ZANARDI, O. C.; GARLET, J. Levantamento de doenças em viveiro florestal clonal no cone sul de Rondônia. Enciclopédia Biosfera, v. 10, n. 19; p. 124I-1249, 2014. 